\title{
Konsep Pendidikan Mobile Learning: Layanan Konseling
}

\author{
M. Rizki Nasution ${ }^{1 *}$, Lailan Sari Nasution ${ }^{2}$ \\ 1 Ilmu Ekonomi, Fakultas Ekonomi dan Bisnis, Universitas Sumatera Utara, 20155 Medan, Indonesia \\ 2 SMP Negeri 3 Siempat Nempu, 22261 Kab. Dairi, Indonesia \\ "Corresponding author:muhkition@gmail.com
}

Received: 11 August 2021; Accepted: 20 August 2021; Published: 23 August 2021

\begin{abstract}
Abstrak: Peningkatan Pandemi Covid-19 di Indonesia membuat perubahan kebijakan pendidikan. Menanggapi itu, pemerintah membuat kebijakan tentang kurikulum darurat sebagai bentuk konsep dasar yang dapat dijalankan pada saat kondisi tertentu. Konseptualisasi dasar pendidikan dengan kurikulum 2013 tidaklah bisa berjalan dengan baik, sehingga pemerintah mengambil keputusan bagi pendidikan yang terdampak Covid-19 dapat menerapkan kurikulum darurat. Pemerintah menekankan bahwa pendidikan di Indonesia harus tetap mementingkan tujuan utama yang terkandung dalam kurikulum. Dengan begitu penelitian ini melihat konsep pendidikan dengan M-Learning dari perspektif layanan konseling. Program penting bimbingan dan konseling di sekolah menjadi peran utama untuk mendapatkan evaluasi yang baik. Tujuan penelitan ini untuk mengevaluasi sistem pembelajaran M-Learning dengan memberikan layanan kepada peserta didik dengan membandingkan pembelajaran C-Learning. Pada penelitian ini menggunakan metode evaluasi dengan dasar penelitian kualitatif. Hasil evaluasi menunjukkan bahwa sistem pembelajaran M-Learning inefisiensi dalam konsep pendidikan yang didasari pedoman kurikulum di Indonesia.
\end{abstract}

Kata Kunci: Konsep Pendidikan, M-Learning, C-Learning, Tinjauan Konselor

\begin{abstract}
The increase in the Covid-19 pandemic in Indonesia has led to changes in education policy. In response to that, the government making a policy on the emergency curriculum as a form of the basic concept that can be implemented under certain conditions. The basic conceptualization of education with the 2013 curriculum could not work well, so the government decided for education affected by Covid-19 to apply an emergency curriculum. The government emphasizes that education in Indonesia must continue to prioritize the main objectives contained in the curriculum. Thus, this study looks at the concept of education with M-Learning from the perspective of counseling services. An important program of guidance and counseling in schools becomes the main role to get a good evaluation. The purpose of this research is to evaluate the M-Learning learning system by providing services to students by comparing C-Learning learning. This study using an evaluation method based on qualitative research. The evaluation results show that the M-Learning learning system is inefficient in the concept of education based on curriculum guidelines in Indonesia.
\end{abstract}

Keywords: Education Concepts, M-Learning, C-Learning, Counseling Service

\section{PENDAHULUAN}

Aktivitas pendidikan pada tahun 2020 telah mengalami perubahan yang sangat signifikan terhadap dunia pendidikan. Kegiatan yang seharusnya dilakukan di sekolah oleh peserta didik seperti berinteraksi dengan teman sebayanya dan juga berinteraksi dengan guru menjadi terhambat karena adanya penutupan sekolah dan digantikan dengan pembelajaran secara dalam jaringan/daring (Prawanti, L. T., \& Sumarni, W., 2020). Ini menyebabkan adanya perubahan proses belajar mengajar. Kendala yang terjadi pada pendidikan di 
Indonesia belakangan ini disebabkan dampak dari adanya Pandemi Coronavirus Disease (Covid-19) yang saat ini Juli 2021 masih melambung tinggi. Hal ini didukung oleh Menteri Pendidikan dan Kebudayaan Nadiem Makarim pada Surat Edaran Nomor 4 Tahun 2020 tentang Pelaksanaan Kebijakan Pendidikan Dalam Masa Darurat Penyebaran Covid-19 pada tanggal 24 Maret 2020. Pada pertengahan Maret 2020 di Indonesia langsung menerapkan pembelajaran dari rumah. Seperti temuan Prawanti (2020) yang menjelaskan bahwa pembelajaran yang biasanya dilakukan di sekolah sekarang menjadi belajar di rumah untuk memutuskan rantai penularan pandemik Covid-19. Sehingga menjadi tantangan bagi pendidik untuk memberikan pembelajaran dengan inovasi baru. Dalam UU No. 14 Tahun 2005 pendidik telah di beri amanah dan ditunutut untuk memiliki kualifikasi akademik, kompetensi, sertifikasi pendidik, sehat jasmani dan rohani, serta memiliki kemampuan untuk mewujudkan tujuan pendidikan nasional.

Pendidikan di Indonesia sebelumnya menggunakan sistem pendidikan yang semula konvensional artinya bertatap muka dan dilakukan dengan aktivitas pada waktu tertentu dan lokasi yang sudah ditentukan. Menurut Munir (2009) maka dengan sentuhan teknologi informasi khususnya dunia cyber beralih menjadi sistem pendidikan jarak jauh yang tidak dibatasi oleh ruang, waktu, dan jarak, sehingga hubungan antara pembelajar dan pengajar bisa dilakukan kapan saja dan dimana saja. Pembelajaran online merupakan bentuk pembelajaran/pelatihan jarak jauh dengan memanfaatkan teknologi telekomunikasi dan informasi, misalnya internet, CD-ROOM (Arizona, 2020). Menurut Syahfitri et al., (2020) menjelaskan bahwa pembelajaran secara daring yang dilakukan oleh guru saat ini hanya sebatas pada aktivitas transfer of knowledge. Dengan demikian masih adanya aspek pendidikan secara konvensional yang tidak bisa diserap dan dilakukan dengan menggunakan media tertentu dari rumah / jarak jauh.

Pendidik sangat membutuhkan arah yang tepat untuk mengatasi kekurangan dari pembelajaran di rumah. Sehingga dapat melaksanakan kegiatan belajar mengajar seperti layaknya berada di sekolah. Sebelum adanya pandemi Covid-19 pendidikan di Indonesia telah melakukan penerapan Kurikulum 2013. Dimana aspek yang diminta adanya hubungan timbal balik antara pendidik dan peserta didik dengan pendekatan saintifik. Kurikulum 2013 sangat menekankan adanya peningkatan pola fikir peserta didik, penguatan pembelajaran individu dan kelompok, penguatan pola pembelajaran berbasis klasikal-massal dengan tetap memperhatikan pengembangan potensi khusus yang dimiliki setiap peserta didik, dan pola pembelajaran kritis. Ancaman bagi pendidik terhadap sikap dan moral peserta didik akan terjadi dimana peserta didik bebas menggunakan gadget. Padahal dalam Kurikulum 2013 sangat menekankan adanya peningkatan keseimbangan antara sikap spiritual dan sosial, pengetahuan, dan keterampilan, serta menerapkannya dalam berbagai situasi di sekolah dan masyarakat. Pemerintah sangat aktif dan tegas memberikan perintah kepada setiap sekolah baik tingkat paling rendah (Sekolah Dasar) hingga perguruan tinggi bahwa pada saat kasus pandemi Covid-19 sangat tinggi proses daring yang dilakukan dengan pembelajaran di rumah. Dalam keputusan menteri pendidikan dan kebudayaan Republik Indonesia Nomor 719/P/2020 Tentang Pedoman Pelaksanaan Kurikulum Pada Satuan Pendidikan dalam Kondisi Khusus. Kondisi khusus adalah kondisi dimana suatu keadaan bencana yang telah ditetapkan pemerintah pusat atau daerah. Dengan kebijakan pemerintah bahwa setiap sekolah yang memiliki kasus Covid-19 tinggi dapat melakukan Kurikulum Darurat yang telah di tetapkan pemerintah. Kurikulum darurat menekankan adanya fleksibilitas pada satuan pendidikan untuk menentukan kurikulum yang sesuai dengan kebutuhan pembelajaran peserta didik. Artinya tetap melaksanakan penerapan pendidikan dengan kurikulum 2013 dengan fleksibel sesuai kebutuhan pembelajaran peserta didik. Kurikulum darurat sangat menekankan adanya Asesmen Diagnostik, dimana proses pembelajaran yang sangat dibutuhkan dapat menjadi dasar untuk memberikan pembelajaran pada setiap mata pelajaran. Hasil asesmen digunakan oleh pendidik, peserta didik, dan orang tua/wali sebagai umpan balik dalam perbaikan pembelajaran. 
Kajian penelitian ini menampilkan gambaran secara terkhusus dengan memberikan tinjauan aktivitas pendidikan di sekolah dari perspektif Konselor (Guru Bimbingan dan Konseling). Konsep pendidikan yang diperbaharui dengan adanya kebutuhan khusus dikarenakan adanya masalah darurat yang tidak bisa dihindari sekolah yakni Covid-19. Penelitian ini bertujuan untuk mengetahui konsep pendidikan dengan mengevaluasi proses pendidikan sistem Mobile Learning /M-Learning dengan perbandingan sistem Konvensional/ C-Learning (Convensional Learning). Gambaran ini melalui metode evaluasi dengan Kualitatif dimana peneliti memberikan wawancara kepada objek peneliti, sebagai tambahan kajian metode penelitan ini melalui kajian literatur yang valid dan terstruktur untuk mendapatkan hasil yang optimal pada gambaran umum tanpa adanya kepentingan khusus.

\section{METODE PENELITIAN}

Menafsirkan dari beberapa perilaku manusia sebagai perubahan kebijakan dan tindakan program yang akan dilakukan dalam penelitian ini sangat tepat untuk menggunakan metode evaluasi. Menurut Arikunto (2013), melakukan evaluasi program adalah kegiatan yang dimaksudkan untuk mengetahui seberapa tinggi tingkat keberhasilan dari kegiatan yang direncanakan. Sumber data utama dalam penelitian ini merupakan kata-kata dan tindakan, selebihnya data tambahan seperti dokumen dan lain-lain. Menurut Arikunto (2010), berkaitan dengan hal itu pada bagian ini jenis datanya dibagi dalam kata-kata, tindakan, sumber data tertulis, foto dan statistik. Dasar pada penelitian kualitatif adalah ucapan, ungkapan, tindakan dan kesaksian dari subjek yang diteliti. Menurut Spradley (1979) subjek penelitian adalah sumber informasi dalam penelitian, sementara itu menurut Moleong (1990) subjek penelitian adalah orang dalam pada latar penelitian, yaitu orang yang dimanfaatkan untuk memberi informasi tentang situasi dan kondisi latar penelitian. Subjek penelitian ini yaitu Pendidik pelayanan bimbungan dan konseling. Dimana pendidik disebut sebagai konselor telah memami peserta didik pada masa sebelum terjadinya Covid-19. Sumber tambahan meninjau dokument terkait penelitian ini dan dokumentasi konselor pada saat pelayanan bimbingan dan konseling.

Gambaran perilaku yang ditinjau dari penelitian ini yaitu peserta didik kelas IX (Sembilan) di Sekolah SMP Negeri 3 Siempat Nempu yang berada di JI. Pendidikan no. 15 sihorbo kecamatan Siempat Nempu Kabupaten Dairi. Peserta didik kelas IX menjadi sampel penelitan ini dengan pengamatan dokumen peristiwa lalu pada tahun sebelumnya. Gambaran ini menjadi asumsi untuk mendapatkan prioritas atau masalah yang terkait dengan meninjau aspek terdahulu dari peritiwa lalu. Penelitian ini memberikan penjelasan tentang perbandingan sistem pendidikan konsep belajar M-Learning dengan konsep belajar C-Learning sebagai tolok ukurnya melalui pengamatan dan pengalaman yang dilakukan pendidik yaitu Konselor di sekolah.

Penelitian ini berfokus pada analisa yang diberikan oleh konselor yang telah memberikan layanan konseling kepada peserta didik. Sebagai tambahan untuk memperkuat analisa konselor peneliti menambah kajian literatur yang validitasnya telah terpercaya dan terbaru untuk menciptakan hasil yang baik dan terpercaya. Penelitian kualitatif umumnya menggunakan wawancara tidak berstruktur atau semi berstruktur (Holloway \& Wheeler, 1996). Sedangkan dalam hal ini konselor menambahkan pelayanan berupa wawancara kelompok.

\section{HASIL DAN PEMBAHASAN}

Pendidikan yang terstruktur pada konsep dasar pendidikan menjadikan tolok ukur pada penelitian ini. Struktur dasar untuk menjadi dasar pencapaian yang akan di terima oleh peserta didik yaitu Kurikulum. Kurikulum sebagai konseptualisasi pendidikan dimana terdapat rancangan sejumlah mata pelajaran. Menurut Taba (1962), kurikulum sebagai a plan or learning, yakni sesuatu yang direncanakan untuk dipelajari oleh peserta didik. Sekolah mempunyai pedoman untuk setiap mata pelajaran berupa silabus. Silabus merupakan 
penjabaran dari standar isi kurikulum, yang kemudian dioperasionalkan dalam rencana pelaksanaan pembelajaran (RPP). Selain itu proses dasar utama yang di rancang pendidik untuk menjadi acuan yang harus berjalan saat terjadinya proses pembelajaran berlangsung berupa RPP. RPP merupakan rancangan pembelajaran pada setiap mata pelajaran yang akan diterapkan pendidik dalam pembelajarannya di kelas.

\section{Hasil Penelitian}

Penelitian ini berlatar di Sekolah Menengah Pertama (SMP) Negeri 3 Siempat Nempu yang beralamat di jl. Pendidikan no. 15 sihorbo, kecamatan Siempat Nempu, Kabupaten Dairi. Sekolah ini terletak jauh pusat kota Sidikalang dimana akses internet masih menjadi permasalahan utama pada saat proses daring pada tahun ajaran baru tahun 2020. Akses masuk jaringan internet masih kurang dengan sinyal yang lemah akan tetapi proses daring masih dapat terlaksanakan dan masih ada beberapa pendidik langsung secara door to door ke rumah untuk menjumpai peserta didik dalam interaksi belajar untuk memberikan arahan langsung untuk pengaplikasian $M$-Learning dan juga proses tahap pembelajaran. Mengingat hal tersebut pendidik harus bekerja lebih keras akan tetapi semangat pendidik juga diapresiasi oleh kepala sekolah dalam tindakan mencegah penularan Covid-19 dan mengantisipasi peserta didik yang tidak bisa melakukan pembelajaran online atau belom mengerti tentang metode M-Learning. Pada awal tahun 2021 pendidik di SMP Negeri 3 Siempat Nempu sepakat tidak lagi melakukan pembelajaran secara door to door mengingat adanya perkembangan Covid-19 yang meningkat. Aksi ini dihentikan atas kebijakan dari kepala sekolah agar pendidik tak lagi melakukan pembelajaran dengan metode door to door. Berikut merupakan latar depan SMP Negeri 3 Siempat Nempu.

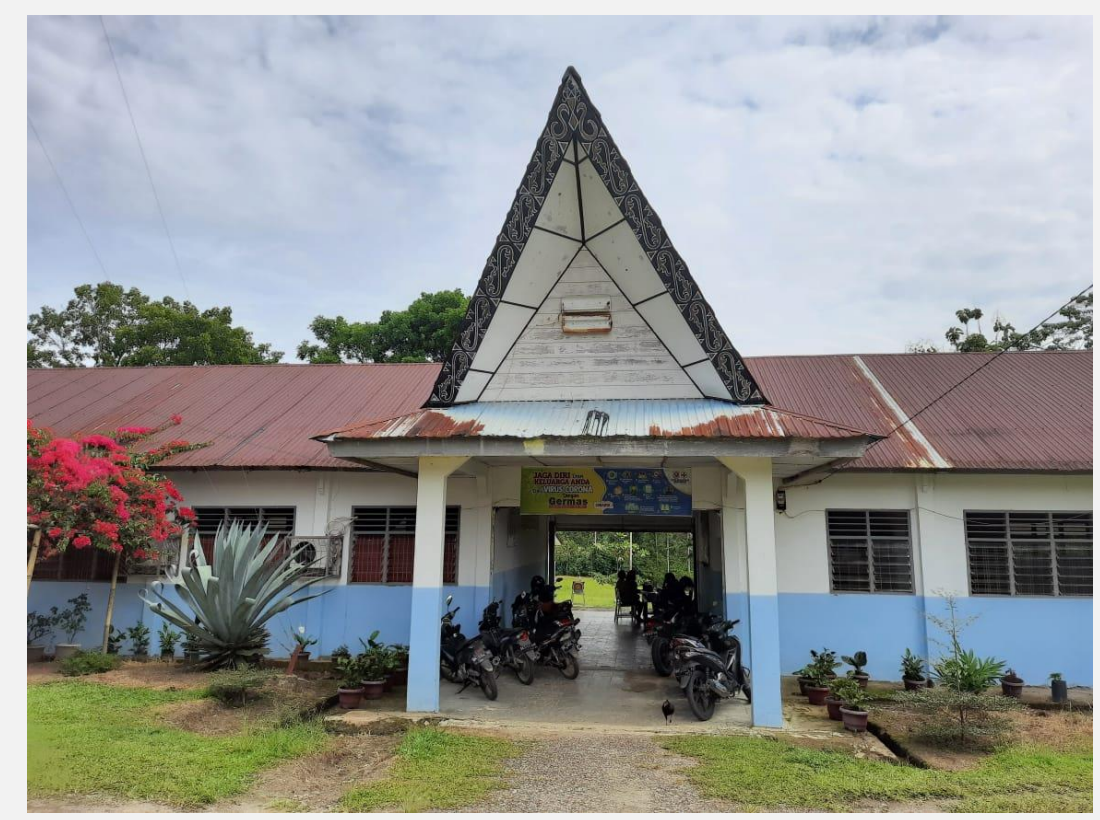

Gambar 1. Latar Depan SMP Negeri 3 Siempat Nempu (Sumber: Olah Gambar Peneliti, 2021)

Hasil penelitian ini diperoleh secara langsung dengan bantuan konselor yang menjadi sumber utama data penelitian. Pembelajaran yang saat ini dilakukan secara daring dengan pembelajaran M-Learning masih memberikan hasil kebaharuan yang dapat berjalan dengan baik untuk mencegah penularan Covid-19 pada saat ini. Namun nyatanya tidak dapat mempertahankan tujuan dasar yang tercantum dalam kurikulum. Berikut data perbandingan antara $M$-Learning dengan C-Learning. 
Tabel 1. Perbandingan Pembelajaran M-Learning dengan C-Learning

\begin{tabular}{clll}
\hline No & \multicolumn{1}{c}{ Keterangan } & \multicolumn{1}{c}{ M-Learning } & \multicolumn{1}{c}{ C-Learning } \\
\hline 1 & Akses Pencapaian dengan Kurikulum & Kurikulum Darurat & Kurikulum 2013 Revisi \\
2 & Silabus sebagi pedoman dasar & Standar Isi Kurikulum \\
3 & Kompetensi inti tercapai secara maksimal & Cukup Terpenuhi & Standar Isi Kurikulum \\
pada setiap mata pelajaran & Memenuhi (Proses & Terlaksana) \\
4 & Kompetensi dasar setiap mata pelajaran & Cukup Terpenuhi & $\begin{array}{l}\text { Memenuhi (Proses } \\
\text { Terlaksana) }\end{array}$ \\
5 & Alokasi waktu & Fleksibelitas Dengan & $\begin{array}{l}\text { Ketepatan Waktu Secara } \\
\text { Wmum }\end{array}$ \\
6 & $\begin{array}{l}\text { Peningkatan pembelajaran dalam } \\
\text { pengetahuan }\end{array}$ & Sangat Meningkat & Sangat Meningkat \\
7 & $\begin{array}{l}\text { Peningkatan pembelajaran dalam } \\
\text { keterampilan }\end{array}$ & Meningkat & Sangat Meningkat \\
8 & $\begin{array}{l}\text { Sikap peserta didik dalam proses } \\
\text { pembelajaran }\end{array}$ & Cukup Aktif & Aktif \\
9 & $\begin{array}{l}\text { Sikap spiritual peserta didik } \\
\text { Sikap sosial peserta didik }\end{array}$ & Tidak Terpenuhi & Terpenuhi \\
\hline
\end{tabular}

Dari Tabel 1 menjelaskan bahwa adanya perbandingan mendasar pada saat proses belajar mengajar berlangsung. Pada poin 1 menjabarkan akses pencapaian dengan kurikulum darurat pada proses pembelajaran M-Learning yang dilakukan SMP Negeri 3 Siempat Nempu masih kurang maksimal. Terbukti adanya temuan Konselor dimana pendidik mata pelajaran Bahasa Indonesia, Agama, Matematika, Pendidikan Jasmani memberikan penjelasan dengan satu arah. Bukan hanya dalam pengetahuan dan keterampilan saja, melainkan sosial dan spritual juga memberikan pembelajaran dengan satu arah. Proses pembelajaran ini jauh berbeda di rasakan oleh pendidik dimana saat pembelajaran C-Learning dapat memberikan respon baik dari dua arah. Pada poin 3 memberikan penjelasan perbandingan dimana $\mathcal{M}$ learning tidak dapat memberikan pemenuhan secara maksimal dari kompetensi inti. Kompetensi inti terdiri dari aspek spritual, sosial, pengetahuan dan keterampilan. Dalam pemenuhan RPP terlaksana dengan baik adanya proses interaksi awal yang dapat memberikan peningkatan nilai nilai sosial dan spritual peserta didik. Namun demikian temuan konselor dari teman-teman pendidik memberikan keluhan bahwa adanya masalah jaringan pada saat pembelajaran daring melalui google meet memberikan dampak dimana pendidik tidak memberikan fokus utama dimana sasaran utama pendidik hanya menyampaikan ilmu pengetahuan saja. Ini sangat berbanding terbalik pada saat pembelajaran C-Learning dimana proses pemenuhan kompetensi inti berjalan secara optimal.

Adanya ketidaksetaraan materil pada peserta didik menjadikan masalah utama dalam belajar. Dimana tidak semua peserta didik mempunyai gadget. Sesuai dengan artikel dari Nasution (2020), adanya kendala diantaranya masalah ketersediaan perangkat berupa laptop atau telepon pintar yang tidak dimiliki oleh semua siswa. Temuan konselor juga mendapatkan hal yang sama dari layanan bimbingan konseling bahwa adanya peserta didik tidak memiliki gadget berupa Smartphone/Laptop sebagai sarana pembelajaran. Hasilnya pendidik di SMP Negeri 3 Siempat Nempu memberikan waktu jeda dalam pemenuhan absensi kelas dan kumpul tugas. Dengan demikian peserta didik yang jika ada kakak atau tetangga yang memiliki smartphone dapat meminjamnya untuk mengirimkan tugas dengan cara dapat bertanya kepada teman sekelas yang sudah melaksanakan daring. Berikut adalah gambaran layanan konseling salah satu peserta didik. 


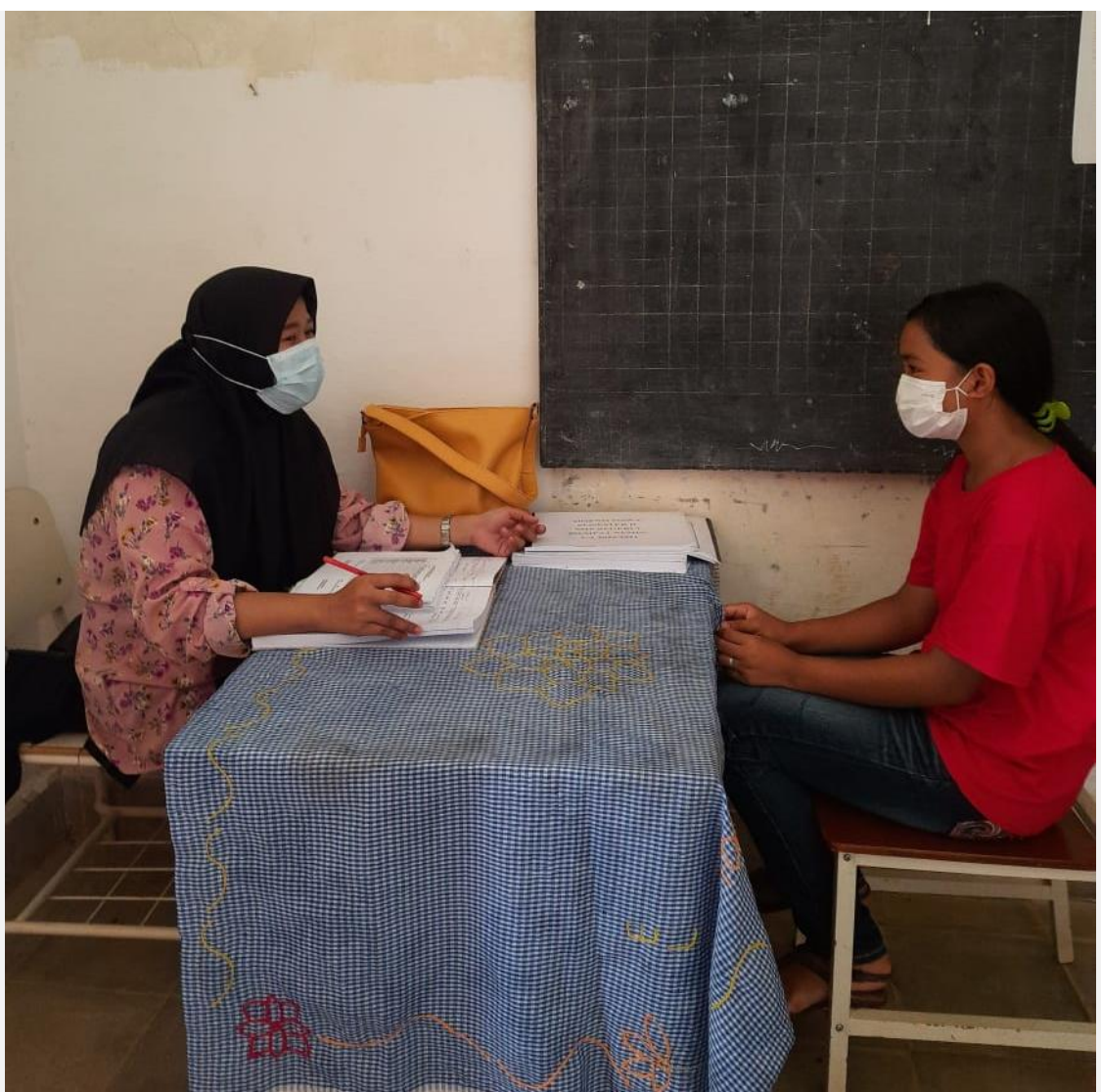

Gambar 1. Layanan Konseling Kelas IX Pada Saat Pembelajaran Online (Sumber: Olah Gambar Konselor, 2021)

Aktifikas ditinjau secara pengalaman konselor dengan memberikan pelayanan konseling kepada peserta didik baik itu sebelum pembelajaran online (Pembelajaran di sekolah dengan tatap muka) ataupun Pembelajaran Jarak Jauh (belajar dalam rumah). Pelayanan konseling ini dilakukan di sekolah pada jam 15.00 WIB dengan memberikan jadwal tertentu kepada setiap peserta didik dengan layanan individu. Pada pelayanan konseling di saat pendemi tetap melaksanakan dengan protokol kesehatan sesuai anjuran pemerintah.

Perubahan tingkah laku anak yang cenderung pada tahap pertumbuhan mengalami percepatan yang sangat signifikan. Adanya pembelajaran online memberikan ketidaknyamanan dalam belajar terhadap peserta didik. Banyaknya tugas yang menumpuk membuat peserta didik cenderung malas dengan adanya tambahan peningkatan pemakaian ponsel yang berlebih. Dampaknya akan adanya stress pada peserta didik. Stress adalah pengalaman emosi yang negatif yang disertai dengan perubahan fisiologis, kognitif dan perilaku (Taylor, 1995). Perubahan ini hampir seluruh peserta didik merasakan pada saat layanan diberikan. Terbukti dari penjelasan kenselor dalam tahan wawancara bahwa terdapat 14 peserta didik (tidak disebutkan gendernya) dari 26 peserta didik melakukan pembelajaran dari di dalam kamar tidur pada saat pembelajaran jarak jauh. (Jakcson \& Cochran, (1991); Saurabh \& Ranjan, (2020)) menyatakan dalam artikelnya bahwa terisolasi secara sosial dan kesepian membawa dampak berkelanjutan bagi remaja, yaitu peningkatan distress psikologis, dimana kesepian dapat menyebabkan rendahnya self-esteem, menyalahkan diri, merendahkan diri, dan depresi. Layanan juga diberikan sebelum proses belajar normal (belajar di sekolah dengan tatap muka). Dalam hal ini menggambarkan setiap aktifitas peserta didik dalam proses pembelajaran C-Learning. 


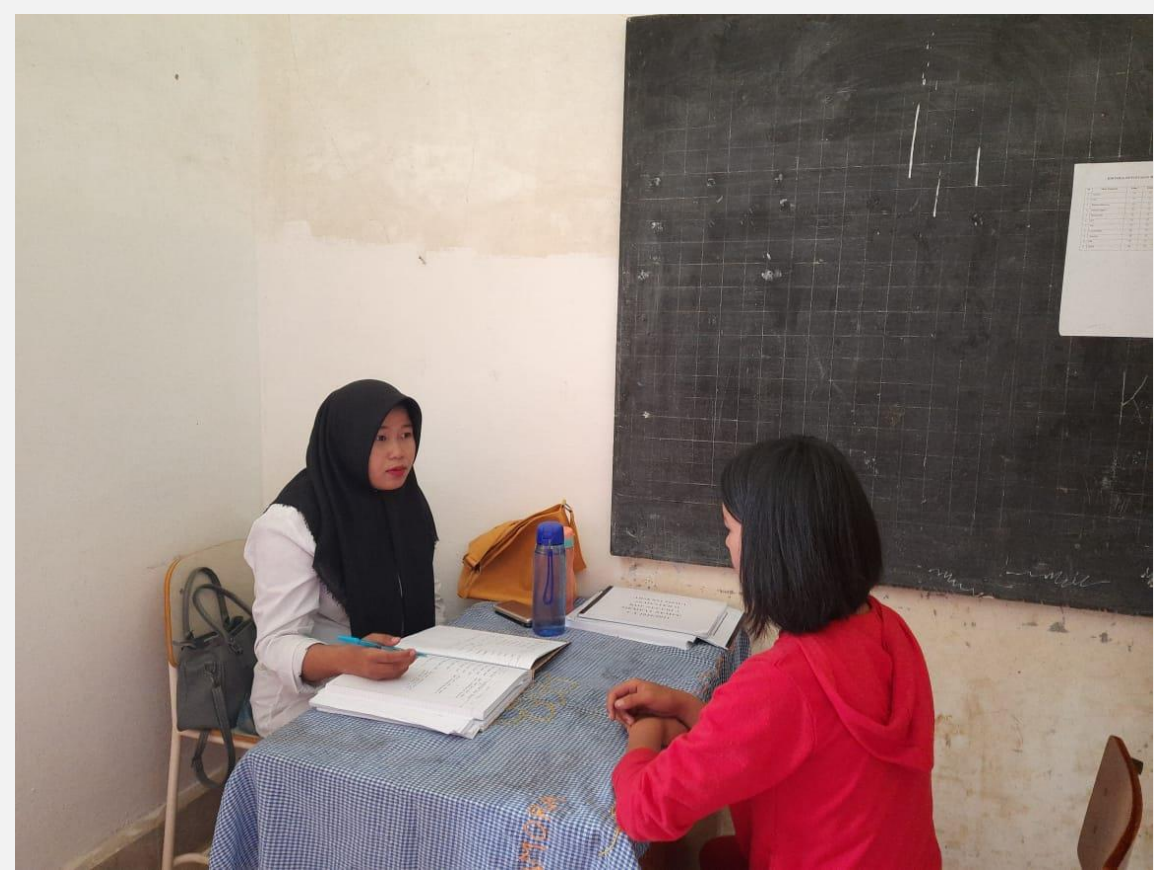

Gambar 2. Layanan Konseling Kelas VII SMP Negeri 3

(Sumber: Olah Gambar Konselor, 2019)

Perkembangan jasmani dan rohani peserta didik sangat baik dari hasil pelayanan yang telah dilakukan. Menurut pengamatan konselor dalam catatan buku besar Bimbingan Konseling dan dokumen terkait terdapat seluruh peserta didik mendapatkan perkembangan dengan sosialiasi sesama peserta didik dan juga pendidik. Hal ini meningkatkan emosional yang baik dalam proses pembelajaran berlangsung sehingga lebih mudah menyerap ilmu yang diberikan oleh pendidik. Adanya perubahan pada peserta didik seperti imajinasi yang tumbuh berlebih saat duduk bangku sekolah dasar (SD) yang terbentuk diri anak usia 7 hingga 10 tahun secara bertahap yang fantastik tersebut menjadi lebih realistis ketika ia masuk sekolah menengah pertama. Adanya bakat dan minat yang terlihat pada potensi peserta didik secara jelas. Meningkatnya insting peserta didik, dengan dorongan sosial, dan bantuan pendidik mampu mangasah naluri peserta didik. Salah satu contoh yang diterapkan di sekolah SMP Negeri 3 Siempat Nempu adanya pertanyaan sebelum belajar, mengikuti pembelajaran dengan semangat, bekerja sama membersihkan lingkungan kelas dan bergotong royong dalam lingkungan sekolah. Psikologis peserta didik pada pembelajaran tatap muka di sekolah juga menimbulkan resiliensi. Resiliensi adalah kapasitas untuk merespon secara sehat dan produktif ketika berhadapan dengan kesengsaraan atau trauma, yang diperlukan untuk mengelola tekanan hidup sehari-hari (Reivich \& Shatte, 2002). Adanya trauma baik itu di lingkungan keluarga, lingkungan sekolah ataupun lingkungan sosial keseharian menjadi tekanan peserta didik untuk merespon kedewasaan.

Korelasi yang sama bahwa butuhnya kerjasama pendidik dan orangtua peserta didik sangat mendorong perilaku dan sikap untuk meningkatkan perkembangan usia remaja baik dalam aspek psikologis, kognitif dan keterampilan peserta didik. Ini juga berlaku pada pembelajaran jarak jauh ataupun pembelajaran di sekolah.

\section{Pembahasan}

Penelitian ini manganalisa adanya ketidakpastian untuk mencapai tujuan yang telah di buat pemerintah yang diterapkan pada kurikulum nasional. Menurut Sanjaya, J. B., (2020) Hak pendidikan yang tidak terpenuhi, menjadikan pemerintah untuk menetapkan kebijakan Kurikulum Darurat. Pembelajaran M-Learning membantu tatanan pendidikan tetap berjalan 
dengan baik untuk tetap meningkatkan ilmu pengetahuan. Namun demikian banyaknya dampak negatif yang harus diterima peserta didik masih belom mampu untuk mengurangi resiko tersebut. Penelitian ini mengambil data dari artikel Estikasari, P., \& Pudjiati, S. R. R., (2020) yang berjudul Gambaran Psikologis Remaja Selama Sekolah Dari Rumah Akibat Pandemi Covid-19. Hasil penelitian tersebut mengungkapkan data distribusi perasaan partisipan dari jumlah observasi sebesar 190 orang dengan persentasi jenis perasaan Bosan sebesar 20,26\%. Artinya bahwa pembelajaran M-Learning sangat membutuhkan emosional lebih tinggi sehingga peserta didik cenderung bosan. Bertolak belakang dengan Marotz (2013) yang menyatakan bahwa Remaja memiliki semangat yang tinggi untuk belajar, mencari tahu, dan berusaha untuk berdaya serta membuat perbedaan-perbedaan di lingkungannya.

Konseptualiasi pendidikan dengan dasar kurikulum menjadi pedoman dasar pendidikan. Kurikulum di indonesia telah banyak direvisi untuk meningkatkan kualitas anak bangsa yang nantinya bisa menjadi sumber saya manusia berkualitas. Revisi pemerintah pada kurikulum yaitu Kurikulum 2013 revisi, dimana diharapkan mampu menyamakan tingkatan kualitas pendidikan di dunia. Tantangan pendidikan muncul ketika adanya pandemi yang mengharuskan pembelajaran jarak jauh dengan mempertimbangkan aspek kesehatan. Ini menjadi kewaspadaan pada pendidik, dimana kendala pada proses pembelajaran masih banyak ditemukan dalam keigatan belajar mengajar. Tak menutup kemungkinan adanya masalah pembelajaran $M$-learning tidak memenuhi dasar kurikulum tersebut. Selain itu sukses tidaknya implementasi kurikulum tersebut terlihat dari pendidik yang memberikan pembelajaran. Kondisi ini menunjukkan bahwa fungsinya kurikulum terletak pada bagaimana implementasi di sekolah, khususnya di kelas dalam kegiatan pembelajaran, yang merupakan kunci keberhasilan tercapainya tujuan, serta terbentuknya kompetensi peserta didik. Konselor memberikan pendapat bahwa pendidik di sekolah ini memiliki lima pendidik yang sudah senior dimana proses pemakaian gadged untuk memberikan edukasi dan inovasi belajar menjadi kurang.

Tujuan pendidikan terdiri atas telah tercantum pada undang-undang No. 20 tahun 2003 dimana pendidikan di Indonesia lebih menekankan pada aspek Spiritual dan sosial. Menurut Sujana (2019) Pendidikan diharapkan menambah keimanan terhadap Allah Tuhan Yang Maha Esa serta meningkatkan pembangunan dan kemajuan politik, ekonomi, sosial, budaya, dan pertahanan keamanan.

\section{KESIMPULAN}

Analisa konselor, wawancara dan tambahan kajian literatur dapat disimpulkan bahwa pendidikan dengan sistem pembelajaran M-Learning menjadi harapan baru untuk alternatif dalam kasus di Indonesia yang terjadinya wabah pandemi Covid-19 akan tetapi belum bisa memberikan kepastian untuk merubah perilaku peserta didik yang pastinya akan bisa dilakukan saat proses sistem pembelajaran C-Learning berlangsung. Perubahan konsep belajar menurunkan prestasi peserta didik, meningkatkan stres yang lebih tinggi, dan tidak memiliki jalur unutk meningkatkan bakat yang disebabkan keterbatasan mata pelajaran pada kompetensi dasar yang harus dihilangkan pada konsep kurikulum darurat akan tetapi dapat mempertahankan hak pendidikan. Konsep dasar pendidik yaitu kurikulum haruslah tetap terlaksana dengan baik. Tetap mempertahankan nilai-nilai sosial dan tetap neningkatkan aspek spritual yang harus ditanamkan pada setiap peserta didik.

\section{UCAPAN TERIMA KASIH}

Ucapan terima kasih kepada SMP Negeri 3 Siempat Nempu yang telah bekerja sama untuk penelitian ini.

DAFTAR PUSTAKA

Arikunto, S. (2010). Prosedur Penelitian: Suatu Pendekatan Praktik (Cet. 14). Jakarta: Rineka Cipta. 
Arikunto, S. (2013). Dasar-Dasar Evaluasi Pendidikan (Edisi 2). Jakarta: Bumi Aksara.

Arizona, K., Abidin, Z., Rumansyah, R. (2020). Pembelajaran Online Berbasis Proyek Salah Satu Solusi Kegiatan Belajar Mengajar di Tengah Pandemi Covid-19. Jurnal Ilmiah Profesi Pendidikan, 5(1), 64-70. https://doi.org/10.29303/jipp.v5i1.111

Estikasari, P., \& Pudjiati, S. R. R. (2021). Gambaran Psikologis Remaja Selama Sekolah Dari Rumah Akibat Pandemi Covid-19. Psikobuletin: Buletin Ilmiah Psikologi, 2(1), 23. https://doi.org/10.24014/pib.v2i1.11750

Holloway, I \& Wheeler, S. (1996). Qualitative re-search for nurses. London: Blackwell Science.

Jackson, J., \& Cochran, S. (1991). Loneliness and psychological distress. The Journal of Psychology, 125(3). 257-262. https://doi.org/10.1080/00223980.1991.10543289

Kemdikbud. (2020). Kepmendikbud Nomor 719/P/2020 tentang Pedoman Pelaksanaan Kurikulum pada Satuan Pendidikan dalam Kondisi Khusus. www.Kemdikbud.go.id, 022651, 9. https://www.kemdikbud.go.id/main/blog/2020/08/kemendikbudterbitkan-kurikulum-darurat-pada-satuan-pendidikan-dalam-kondisi-khusus

Marotz, L.R. \& Ellen, K.E. (2013). Developmental profiles: Pre-Birth through adolescence (7th ed). California: Wadsworth.

Moleong, L. J. (1990). Metodologi Penelitian Kualitatif. Bandung: Rosda Karya.

Munir, M. (2009). Pembelajaran Jarak Jauh Berbasis Teknologi Informasi dan komunikasi. Bandung: Alfabeta.

Nasution, M.R. (2020). Covid-19 Tidak Menjadi Hambatan Pendidikan di Indonesia? https://www.researchgate.net/publication/340923449

Prawanti, L. T., \& Sumarni, W. (2020). Kendala Pembelajaran Daring Selama Pandemic Covid19. In Prosiding Seminar Nasional Pascasarjana (PROSNAMPAS) (Vol. 3, No. 1, pp. 286-291).

Sanjaya, J. B. (2020). Implementasi Kurikulum Darurat di Masa Pandemi COVID-19 Dalam Upaya Pemenuhan Hak Pendidikan. JIL: Journal of Indonesian Law, 1(2), 161-174. https://doi.org/10.18326/jil.vli2.161-174

Sujana, I. W. C. (2019). Fungsi Dan Tujuan Pendidikan Indonesia. Adi Widya: Jurnal Pendidikan Dasar, 4(1), 29-39. https://doi.org/10.25078/aw.v4i1.927

Saurabh, K., \& Ranjan, S. (2020). Compliance and Psychological Impact of Quarantine in Children and Adolescents due to Covid-19 Pandemic. The Indian Journal of Pediatrics, 87(7), 532-536. https://doi.org/10.1007/s12098-020-03347-3

Surat Edaran Nomor 4 Tahun 2020 tentang Pelaksanaan Kebijakan Pendidikan dalam Masa Darurat Penyebaran Covid-19. http://pgdikmen.kemdikbud.go.id/read-news/suratedaran-mendikbud-nomor-3-tahun-2020

Spradley, J. P. (1997). The Etnograpihic Interview (Edisi terjemahan Misbah Zulfa Elizabeth). Yogyakarta: Tiara Wacana.

Reivich, K \& Shatte, A. (2002). The Resilience Factor: 7 Essential Skill for Overcoming Life's Inevitable Obstacle. New York: Broadway Books. 
Republik Indonesia. (2005). UNDANG-UNDANG REPUBLIK INDONESIA NOMOR 14 TAHUN 2005. Tentang Guru dan Dosen. Jakarta: Mentri Hukum dan Hak Asasi Manusia.

Taba, H. (1962). Curriculum Development and Practice. New York: Harcourt Brece and World.

Taylor, S. (1995). Health Psychology. New York: McGraw Hill.

(C) 10 Copyright (c) 2021 by the authors. This work is licensed under
a Creative Commons Attribution-ShareAlike 4.0 International
License. 